\title{
Migration and Networks: Does Education Matter more than Gender?
}

\author{
Michel Beine \\ Sara Salomone
}

CESIFO WORKING PAPER No. 3010

CATEGORY 4: LABOUR MARKETS

APRIL 2010

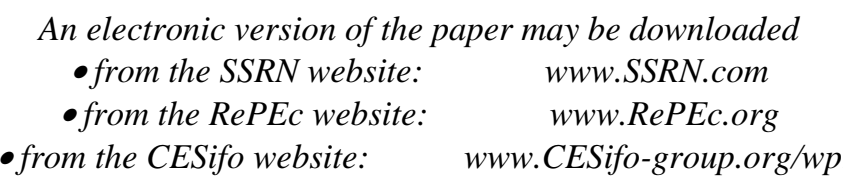




\title{
Migration and Networks: Does Education Matter more than Gender?
}

\begin{abstract}
This paper looks at the impact of networks on international migration flows to OECD countries. In particular, we look at whether diaspora effects are different across education levels and gender. Using new data allowing to include both dimensions, we are able to analyze the respective impact of networks on the proportion of each category of migrant. Therefore, unlike the preceding literature on macro determinants of international migration, we can identify the respective factors influencing the selection in terms skills and in term of gender. We found that network effects vary by education level but not by gender. Women are also found to be less directly dependent on migration costs unrelated to networks such as distance.
\end{abstract}

JEL-Code: F22, O15.

Keywords: migration, human capital, network/diaspora externalities, gender.

Michel Beine

Department of Economics

University of Luxembourg

162a av. de la Faienceri

L - 1511 Luxembourg

michel.beine@uni.lu

\author{
Sara Salomone \\ Catholic University of Louvain \\ Belgium \\ sara.salomone@uclouvain.be
}

March 31, 2010

This article is part of a research project on 'Brain drain, return migration and South-South migration: impact on labor markets and human capital' financially supported by the Austrian, German, Korean, and Norwegian governments through the Multi-donor Trust Fund on Labor Markets, Job Creation, and Economic Growth administered by the World Bank's Social Protection and Labor unit (contract 7152391). The second author also acknowledges financial support from the Belgian French-speaking Community (convention ARC 09/14-019 on 'Geographical Mobility of Factors'). The paper has been presented at seminars at the University of Freiburg, Switzerland, University of Geneva, Switzerland and University of Louvain, Belgium, University of Paris X, France and at conferences including the Third TOM Meeting, Hamburg. The paper benefitted from useful comments and suggestions made by A. Bhargava, P. Crifo, F. Docquier, V. Grossmann, T. Madies, J. De Melo, T. Mueller, M. Orraleaga, D. Stadlemann. 


\section{Introduction}

Migrants' networks have been found to exert important economic effects. Networks favour further migration of people, movement of goods, capital, and ideas across national borders is enhanced (see Rauch and Casella, 1998, Rauch and Trindade, 2002, Munshi, 2003, Rauch, 2003, Gao, 2003, Rapoport and Kugler, 2006, Docquier and Lodigiani, 2008). The stock of people born in the same country and living abroad is indeed able to generate among other things a preferential path for future migrants of the same origin through the decrease of migration costs (either economic and psychological) and tends to overshadow the role of traditional covariates (Massey, 1993). There exists an extensive literature in sociology and economics on migrants'networks. This paper is related to a set of different strands of the extensive literature concerned by the role of migrants' networks.

The interaction between networks and education has been recently addressed in a set of papers. For instance, Beine et al. (2009) look at the role of migrants' diasporas for migration patterns by focusing on the educational level of the migrants. Network effects have been found to be more important for less skilled workers (McKenzie and Rapoport, 2007) and crucial in terms of skill composition of further migration flows (Beine et al. 2009).

Another strand of the literature has looked at the impact of traditional determinants (including networks) on female international migration. Females have been found to be affected mainly through family reunification (Jasso and Rosenzweig, 1986; Davis and Winters, 2001). Basically, diasporas exert two effects: it reduces migration costs (the so-called network effects) and increase the probability of migration through family reunification. As Boyd (1989) emphasizes, it is important to disentangle both effects. Nevertheless, the literature so far has been silent about that. Female migration in general has been extensively addressed in a micro context and in case studies. ${ }^{1}{ }^{2}$ Females are found to be more sensitive to migration costs than men and less willing to leave their country of origin or their family. Curran and Rivero Fuentes, 2003 find that female migrants are more sensitive to networks than male. Some sociological literature (Mahler and Pessar, 2006; Hondagneu-Sotelo,1994; Wiltshire, 1992; Diner, 1983) has justified that result in terms of 'female biological vulnerability' (some natural risk aversion concerning migration decisions) and it has led some researchers to consider females just as 'male migrants de-

\footnotetext{
${ }^{1}$ There are nevertheless a few exceptions in the macro literature such as Dumont, Martin and Spielvogel (2007); Morrison, Schiff and Sjoblom (2007).

${ }^{2}$ One drawback of micro-econometric analyses using individual data is that they often consider a single destination while at the individual level the choice of destination is also important. A macroeconomic analysis considering both the migration decision and the choice of destination is important to capture the impact of important determinants such as the network.
} 
pendent' (as wives, mothers or daughters of male migrants). ${ }^{3}$ On the other hand, genetic evidence has questioned this explanation by documenting a higher female migration rate for humans (Seielstad, Minch and Cavalli-Sforza, 1998). If this last finding turns out to be true, specific economic concerns would arise with the feminization of international migration. Many studies have indeed emphasized the role of females on economic development, and in particular that of educated females on the human capital transmission ${ }^{4}$. In sum, societies that have a preference for not investing in girls or that lose a high proportion of skilled women through emigration may experience slower growth and reduced income.

Finally, another strand of literature, the one concerning migrants' selection, has dealt with the complex mix of self-selection factors (wage differentials, probability to find a job, welfare programs and amenities, migration costs, etc.) and out-selection factors (immigration policies at destination, mobility agreements, etc.) that shape various characteristics of the migration flows (see Grogger and Hanson, 2009; Cohen and Razin, 2008). The gender dimension of the migrants has nevertheless not been considered (except in Cobb-Clark, 1993 as far as wage differentials are concerned).

In this paper, we aim to reconcile those different strands of the existing literatuure. To this aim, we consider explicitly the gender dimension, and we analyse whether the sensitiveness to the above self-selection factors is a matter of education or gender. Integrating jointly in the analysis the gender and the educational dimensions of international migration is likely to be important to assess the respective impact of networks (and other determinants) on migration flows. For instance, analyzes failing to account for the educational level of the migrants might reach misleading conclusions regarding the impact of network on men and women if the skill composition and the gender composition are correlated. For instance, as female migrants from most developing countries are less educated than males ${ }^{5}$ (reflecting thereby differences in the human capital levels among natives), one will tend to spuriously ascribe a role for gender in female migration while the effect is primarily related to education. In a recent paper, Docquier et al. (2008) look at the propensity to migrate for skilled women and men. They show that this propensity is not different but that women are more willing to follow the spouse than men. They do not look however at network effects.

The importance of considering both dimensions of migration is particular strong if for some country pairs, migration flows are highly unbalanced between men and women on

\footnotetext{
${ }^{3}$ Exceptions are Zlotnik (1990, 1995), Cobb-Clark (1993), Cerrutti and Massey (2001) or, more recently, Morrison et al. (2007)

${ }^{4}$ See for example Blackden et al. (2006), Coulombe and Tremblay (2006), Klasen (1999), Knowles et al. (2002), Dollar and Gatti (1999)

${ }^{5}$ See Unesco, 2008
} 
the one hand, and between skilled and unskilled workers on the other hand. The data regarding international migration indeed suggest that there is a huge variability of the gender and the skill composition of the migrant's network. To illustrate, for the year 2000, considering only diasporas larger than 1000 migrants (in order to get rid of outliers), the standard deviation of the share of men in the diaspora is 0.124. Interestingly, the share of men ranges from 5.8 percent to 97.5 percent. ${ }^{6}$ Regarding the skill composition of the diasporas (captured by the share of migrants with tertiary education, the variability is even higher: the standard deviation amounts to 0.20 and the range is between 0.6 percent and 96.4 percent. Such a high variability reflects of course the level of human capital in the origin countries, but also the various factors shaping the skill composition of the migration flows and the extent to which the migrants are positively and negatively selected. Furthermore, for developing countries, the skill composition of the diaspora and of the migration flows is (negatively) correlated with the proportion of women as women tend to be less educated than men, at least in developing countries.

In this paper, we analyze the sensitiveness of each type of migrants to networks. To this aim, we use a new release of the well-known dataset of Docquier and Marfouk (2006) on international migration stocks by educational level and by gender. This allows us to compare the sensitivity of female migrants with the one of men accounting for the level of education. We find that differences in network elasticities are only due to education and not to gender. On the other hand, we find that women are less sensitive to traditional determinants of international migration such as distance

The paper is organized as follows. Section 2 summarizes the main determinants of migration and the selection of migrants. Section 3 presents the data used in the paper while section 4 presents the econometric framework and the empirical results. Section 5 concludes.

\section{Theoretical Background}

In order to isolate the impact of education and gender on the pattern of international migration, it is important to rely on a theoretical framework taking into account the migration decision and the choice of destination for each type of agent. Those decisions have been modeled in the income-maximisation framework initially developed byRoy (1951) and Borjas (1987) and recently extended by Grogger and Hanson (2009) and Beine et

\footnotetext{
${ }^{6}$ For instance, one sees that most of the migrants coming from Thailand or the Philippines to some European countries such as Switzerland, Sweden and Norway are females (see Kremer and Watt, 2006 on this). This is related to migration for the sake of home production. At the other side of the gender spectrum, most migrants from Pakistan and Bangladesh in countries such as Spain or Greece are men.
} 
al. (2009). In those models, the decision rule of each potential migration involves the computation of the net gains associated to each possible outcome. The possible outcomes include the no migration outcome and any international destination. As a result, each individual either chooses to stay in his/her origin country or decides to migrate to the most profitable destination country. In this paper and in line with this theoretical literature, we start from small theoretical model proposed by Beine et al. (2009) in which we introduce the gender dimension. Since the whole structure is similar to the one of Beine et al. (2009), we just summarize the main elements here.

We consider a model of migration with a single skill type in order to model the effects of diasporas. A worker of gender $g$ endowed with $h$ units of human capital earns a wage $w_{i} h$ in country $i$ where $w_{i}$ is the skill price in that country. We assume absence of wage discrimination between men and women. The individual utility is linear in income but also depends on possible moving costs and characteristics of the country of residence. The utility of an individual of gender $g$ and education level $h$ born in country $i$ and staying in country $i$ is given by:

$$
u_{i i, g}(h)=w_{i} h+A_{i, g}+\varepsilon_{i, g}
$$

where $A_{i, g}$ denotes country $i$ 's characteristics (amenities, public expenditures, climate, etc.) that can be gender specific. $\varepsilon_{i, g}$ is a iid extreme-value distributed random term. The utility obtained when the same person migrates to country $j$ is given by

$$
u_{i j, g}(h)=w_{j} h+A_{j, g}-C_{i j, g}(.)-V_{i j}(.)+\varepsilon_{j, g}
$$

The migration costs are divided into two categories. $C_{i j, g}$ captures moving and assimilation costs that are supported by the migrants. These include transportation costs, expenditures to learn a new language, etc ... . Those costs are gender specific in the sense that men and women can have different sensitivities to determinants of those costs, for instance to the size of the network or to distance. $V_{i j}$ represents policy induced costs borne by the migrant to overcome the legal hurdles set by the destination country's government's policies. These costs include visa fees, the bureaucratic barriers for citizenship or even the amount paid to smugglers above the normal cost of transportation when legal entry is restricted. They both depend on the existing diaspora networks and human capital level of the migrant as explained below. The main motivation to differentiate between these two types of costs is to identify the role of government's policy on migration flows and characteristics. The visa costs are not gender specific, as migration policies, either through the selective policies or through the family reunification programs do not discriminate between men and women.

Migration costs, $C_{i j, g}$, depend on factors such as physical distance $\left(d_{i, j}\right)$, destination and origin countries' social, cultural and linguistic characteristics $\left(x_{i}, y_{j}\right)$ as well as human 
capital level $(h)$ of the migrant and the size of the diaspora abroad $\left(M_{i, j}\right)$. Thus, we write

$$
C_{i j, g}(h)=c_{g}\left(d_{i j}, M_{i j}, x_{i}, y_{j} ; h\right)
$$

Distance has a positive effect on migration costs, i.e. $\frac{\partial C_{i j, g}}{\partial d_{i j}}>0$. Nevertheless, the sensitivity might depend on the gender if women pays attention to other factors such as security or discrimination. Because social networks lower information, assimilation and adaptation costs, diaspora has a positive effect on migration through the decrease in migration costs, i.e. $\frac{\partial C_{i j, g}}{\partial M_{i j}}<0$. Finally, we assume that the advantages of being skilled are likely to be more important when the diaspora size is small and migrants can not rely on others. When the diaspora size is larger, the cost advantages of being skilled decline, i.e. $\frac{\partial^{2} C_{i j, g}}{\partial M_{i j} \partial h}>0$.

The legal (or the visa) costs, $V_{i j}$, are determined by the destination country $j$ 's government's policies and depend on various factors. These policies can be specific to sending country $i$ or depend on some individual characteristics of the migrants such as the education level but not on the gender. Many destination countries have specific programs for family reunification or for highly skilled individuals.

Diasporas affect the visa costs mainly through family reunification programs. Let $f_{j}$ denote the generosity of the family reunification program of country $j$ which generally does not discriminate between different origin countries. The probability that a potential migrant from country $i$ has a relative in country $j$ is an increasing function of $M_{i j} / N_{i}$ where $N_{i}$ is the size of the population in country $i$. Thus, the overall effect of reunification programs on visa costs depends on the expression $\frac{f_{j} M_{i j}}{N_{i}}$.

The migrant's human capital level also affects the visa costs if there are selective immigration programs such as the H1-B Visa in the US or the points systems implemented in countries like Australia, Canada, New Zealand or more recently the UK. We denote the generosity of economic migration programs as $e_{j}$ and the overall effect of human capital on visa costs depends on $e_{j} h$. Finally, we formalize the presence of free mobility agreements (such as those between EU members) through a dummy variable $b_{i j}$ which is equal to one if an agreement exists. As a result, we define visa costs as

$$
V_{i j}(h)=\left(1-b_{i j}\right) v\left(\frac{f_{j} M_{i j}}{N_{i}}, e_{j} h\right)
$$

Equation (2) allows to capture the determinants of the visa cost. We have $\frac{\partial V_{i j}}{\partial f}<0$, $\frac{\partial V_{i j}}{\partial e}<0$ and $\frac{\partial V_{i j}^{2}}{\partial e \partial f}>0$. This last term captures that the extent to which an individual relies on family reunion program decreases (resp. increases) when economic program becomes more (resp. less) generous or vice versa. 
In this model, the effect of human capital on visa costs also depends on the size of the diaspora. When the diaspora size is bigger, the probability that a migrant relies on an economic migration program declines and the probability he relies on family reunion programs increases. Hence, we have:

$$
\frac{\partial\left(\partial V_{i j} / \partial h\right)}{\partial M_{i j}}=\left(1-b_{i j}\right) e_{j} \frac{f_{j}}{N_{i}} \frac{\partial V_{i j}^{2}}{\partial e \partial f}>0
$$

Assuming the random term $\varepsilon_{j, g}$ follows an iid extreme-value distribution, one can get the migration flow of individuals of education $h$ and gender $g$ from country $i$ to country $j$ as a proportion of those staying put:

$$
\ln \left[\frac{N_{i j, g}}{N_{i i, g}}\right]=\left(w_{j}-w_{i}\right) h+\left(A_{j, g}-A_{i, g}\right)-C_{i j, g}(.)-\left(1-b_{i j}\right) v\left(\frac{f_{j} M_{i j}}{N_{i}}, e_{j} h\right)
$$

We focus on our main research interest, i.e the diaspora effects on the structure of migration flows. First, from (3), a large diaspora in destination $j$ unambiguously increases current migration flows from $i$ to $j$ for all types of migrants:

$$
\frac{\partial \ln \left[N_{i j, g}(h) / N_{i i, g}(h)\right]}{\partial M_{i j}}=-\left(\frac{\partial C_{i j, g}}{\partial M_{i j}}\right)-\left(1-b_{i j}\right) \frac{f_{j}}{N_{i}}\left(\frac{\partial V_{i j}}{\partial f}\right)>0
$$

The overall impact depends on the effect of networks on migration costs $\frac{\partial C_{i j, g}}{\partial M_{i j}}$ and on the generosity of family reunion programs $\left(f_{j}\right)$ together with the effect on visa costs $\frac{\partial V_{i j}}{\partial f}$ ).

Second, we show that a larger diaspora in country $j$ reduces the 'positive selection' of migrants in terms of education to $j$ from $i$ :

$$
\frac{\partial^{2} \ln \left[N_{i j, g}(h) / N_{i i, g}(h)\right]}{\partial h \partial M_{i j}}=-\frac{\partial C_{i j, g}^{2}}{\partial M_{i j} \partial h}-\left(1-b_{i j}\right) e_{j} \frac{f_{j}}{N_{i}} \frac{\partial V_{i j}^{2}}{\partial e \partial f}<0
$$

Diasporas exert higher effects on the flows of unskilled workers for two reasons : first, in line with the existing literature (see McKenzie and Rapoport, 2009), the decrease in migration costs is larger for unskilled workers and second, diasporas favour family reunification processes that are more important for unskilled workers. As a result, diasporas should increase (resp. decrease) the proportion of unskilled (resp. skilled) migrants at destination.

Third, we can use equation (5) to identify the possible sources of divergence in the sensitivities to network between men and women. Since the second term of equation (5) capturing 
the migration policy part is not gender specific, any difference of the impact of diasporas on the proportion of female and males for a given education level will reflect differences of the impact of the network of migration costs between men and women. In other terms, we have that $\frac{\partial^{2} \ln \left[N_{i j, m}(h) / N_{i i, m}(h)\right]}{\partial h \partial M_{i j}}=\frac{\partial^{2} \ln \left[N_{i j, f}(h) / N_{i i, f}(h)\right]}{\partial h \partial M_{i j}}$ if and only if $\frac{\partial C_{i j, m}^{2}}{\partial M_{i j} \partial h}=\frac{\partial C_{i j, f}^{2}}{\partial M_{i j} \partial h}$. Also, equation (5) makes clear that accounting for the education level is of primary importance to test for differences between men and women since both the impact of the network on migration costs and on the family reunification process depends on the education level.

It is useful to summarize a set of testable predictions. First, through the decrease in migration costs and the family reunification channel, existing networks should favor the international migration of workers. Nevertheless, the impact should be bigger for skilled vs unskilled workers. This implies that the network sensitivities should be negative (resp. positive) on the proportion of skilled (resp. unskilled) migrants. Second, starting from this, it is possible to test, for each education level, whether those sensitivities differ between men and women. Given that the migration policy does not discriminate between men and women, any difference in the estimated sensitivities can be ascribed to the impact of diaspora on migration costs.

In section 4, we focus on the impact of network on the proportion of new migrants and test whether those network sensitivities depend, for a given education level, on the gender.

\section{The Data}

This paper relies on the bilateral version of the database described in Docquier, Lowell and Marfouk (2009), henceforth labeled DLM. This data set characterizes the gender composition of skilled and unskilled migration of all the world countries to the OECD in 1990 and 2000. It is based on immigration data collected in host countries, where information about country of birth, gender, age and educational attainment of immigrants is available. This information is found in national population censuses and registers (or samples of them). More precisely, DLM collected gender-disaggregated data from the 30 members of the OECD, with the highest level of detail on birth countries and three levels of educational attainment: $h=u$ for immigrants with upper-secondary education, $h=s$ for those with post-secondary education and $h=l$ for those with less than uppersecondary education (including lower-secondary, primary and no schooling). Let $M_{t, g, h}^{i, j}$ denotes the stock of adults aged $25+$ born in country $i$ and living in country $j$ at time $t$, of gender $g$ and skill $h .^{7}$ Collecting these numbers in the destination country $j$ gives the

\footnotetext{
${ }^{7}$ As suggested by Beine et al. (2007), we use migration stocks including people ageg 25 or more at time of arrival rather than the total stock of foreign born. The idea is that it allows to include only
} 
stock of emigrants from country $i$ in country $j$, as:

$$
M_{t}^{i j}=\sum_{g} \sum_{h} M_{t, g, h}^{i, j}
$$

For each combination of gender and education level, we can define the share of the flow of migrants of gender $g$ and education $h$ from $i$ to $j$ over the period ranging from $t-1$ to $t$ in the total flow of migrants:

$$
P_{t, g, h}^{i j}=\frac{M_{t, g, h}^{i j}-M_{t-1, g, h}^{i j}}{M_{t}^{i j}-M_{t-1}^{i j}}
$$

Given that we have observations of stocks for 1990 and 2000, we can compute flows and their proportions by category for one single period. The regressand and the main regressor of interest, i.e. the share of each type of migrant by education level and gender and the diaspora networks have been computed by the authors using the above indexes according to proper calculations. Actually, it is more convenient to work with two skill levels. In the benchmark estimations and in line with the existing literature, we consider that skilled agents are those with tertiary education only. Nevertheless, in the robustness analysis, we test the sensitivity of our results to this classification.

In the following section, we relate the migration flows to their determinants. Those determinants include the total initial stock of migrants $M_{t}^{i j}$ (observed in 1990), as well as bilateral variables that are thought to inluence $C_{i j, g, h}$, i.e. the (unobserved) cost supported by one migrants of gender $g$ and education level $h$ to migrate from country $i$ to country $j$. These variables include geodesic distance, colonial links, linguistic proximity and the existence of the shengen agreement between European countries. To deal with the endogeneity of $M_{t}^{i j}$ (see later), we use dummies capturing the historical implementation of some guest worker program. In the robustness analysis, we also use data to capture political rights of female migrants. All those data are explained in Appendix B.

\section{Econometric Analysis}

\subsection{Benchmark Specification}

The benchmark model that we estimate is a four equation system, each equation capturing the impact of determinants on the proportion of each category of new migrants from

migrants that have acquired their education prior to arrival. 
country $i$ to $j$. More precisely, the system is defined as :

$$
\begin{gathered}
S_{t, m, l}^{i, j}=\alpha_{i, m l}+\alpha_{j, m l}+\beta_{m l} D_{t-1}^{i, j}+\sum_{w=1}^{4} \delta_{w, m l} Z_{w}^{i, j}+v_{i, j, t}+\epsilon_{t, m, l}^{i, j} \\
S_{t, f, l}^{i, j}=\alpha_{i, f l}+\alpha_{j, f l}+\beta_{f l} D_{t-1}^{i, j}+\sum_{w=1}^{4} \delta_{w, f l} Z_{w}^{i, j}+v_{i, j, t}+\epsilon_{t, f, l}^{i, j} \\
S_{t, m, u}^{i, j}=\alpha_{i, m u}+\alpha_{j, m u}+\beta_{m u} D_{t-1}^{i, j}+\sum_{w=1}^{4} \delta_{w, m u} Z_{w}^{i, j}+v_{i, j, t}+\epsilon_{t, m, u}^{i, j} \\
S_{t, f, u}^{i, j}=\alpha_{i, f u}+\alpha_{j, f u}+\beta_{f u} D_{t-1}^{i, j}+\sum_{w=1}^{4} \delta_{w, f u} Z_{w}^{i, j}+v_{i, j, t}+\epsilon_{t, f, u}^{i, j}
\end{gathered}
$$

where $S_{t, g, h}^{i, j}$ is the logistic transformation of $P_{t, g, h}^{i, j}$, the share of the flow of migrants between 1990 and 2000 coming from country $i$ to country $j$ of gender $g$ and education level $h .^{8}$ We consider two education levels, low and high, i.e. $h=\{l, u\}$. Highly educated workers are those with tertiary educational achievement while less educated workers comprise either those with post-secondary and less than upper-secondary education. The logistic transformation allows us to rescale the dependent variables on a $0-\infty$ scale rather than to work with bounded variables. This ensures a better behavior of the traditional estimates used in the econometric analysis. Each equation includes $\alpha_{i, g h}$ and $\alpha_{j, g h}$ fixed effects, capturing the impact of unobserved factors specific to origin and destination countries. The impact of the total diaspora is captured through the $\beta$ associated to $D_{t-1}^{i, j}$ which is defined as the log of the total stock of migrants in 1990, i.e. $D_{t-1}^{i, j}=\log \left(M_{t-1}^{i j}\right)$; This implies that the network has a concave impact on the share. In addition to that, we include a set of observable bilateral variables $Z_{w}^{i, j}$ capturing the migration costs from $i$ to $j$ such as the $\log$ of distance, colonial links or the use of a common official language. $\epsilon_{t, g, h}^{i, j}$ is the error term of each equation while $v_{i, j, t}$ is a random variable capturing the influence of additional unobserved bilateral factors influencing $S_{t, g, h}^{i, j}$.

\footnotetext{
${ }^{8}$ Actually, we take the logistic transformation $S_{t, g, h}^{i, j}$ of the proportion of migrants of each type $P_{t, g, h}^{i, j}$. Generally speaking, the logistic transformation is given by $S_{t, g, h}^{i, j}=\eta+\kappa \log \left(\frac{P_{t, g, h}^{i, j}-a}{b-P_{t, g, h}^{i, j}}\right)$. See Johnson (1949). The logistic transformation allows to rescale variables defined on a restricted interval such as $(0,1)$. Those variables have non standard distributions, $\mathrm{J}$ or U-shaped, that preclude classical econometric approaches and that lead to problems of inference in finite samples. In contrast, the logistic transformation gives rise to a logit-normal distribution. Here we take particular values for the parameters of the transformation, with $\eta=0, \kappa=1, a=0$ and $b=1$.
} 
The estimation of system (8-11) allows to test whether the network sensitivities are equal between men and women. In order terms, the key investigation involves to test the validity of the two following null hypotheses : $H_{0,1}: \beta_{m u}=\beta_{f u}$ and $H_{0,2}: \beta_{m l}=\beta_{f l}$.

The use of logistic transformations allows to account for the non standard distributions associated to the use of proportions as the dependent variables. This is important for inference purposes that are central in this paper. Nevertheless, as a robustness check, we also estimate system (8-11) using proportions as the relevant dependent variables. This implies a significantly different approach than the one adopted in the following section. In particular, it involves constrained estimation taking into account that the proportions of migration flows sum up to $1 .^{9}$ We find similar findings with respect to the key elements of investigation, especially concerning the non rejection of $H_{0,1}$ and $H_{0,2}$. The results of that alternative analysis are reported in section 4.4 and in Appendix A1.

\subsection{Econometric issues}

The estimation of system (8)-(11) raises a couple of econometric issues. A first issue is related to the fact that the model involves proportion of migrants' flows. This induces a significant degree of correlation between the error terms of each equation $\epsilon_{t, g, h}^{i, j}$. The correlations between the $S_{t, g, h}^{i, j}$ of each equation ranges from 0.41 to -0.70 . This correlation has to be accounted for to ensure the consistency of the parameter estimates. Therefore, we use SURE method to estimate the system. ${ }^{10}$

The second econometric issue is related to the need to instrument the diaspora in each of the four equations. This issue has explicitely been addressed by Beine et al.(2009). The potential inconsistency of OLS (or SURE) estimates comes from the possible correlation of $D_{t-1}^{i, j}$ with $\epsilon_{t, g, h}^{i, j}$. If there are unobserved factors included in $\epsilon_{t, g, h}^{i, j}$ that are correlated with the size of the diaspora, then failure to identify those factors will lead to some inconsistency in the parameter estimates of (some of) the equations. For instance, some bilateral factors related to resilient discrimination of females of country $i$ in country $j$ will both influence in turn the size of the diaspora $D_{t-1}^{i, j}$ and the proportion of female migrants $S_{t, f, h}^{i, j}$, leading to inconsistency of the parameter estimates of the equations involving female migration. To prevent such a problem, it might be desirable to instrument $D_{t-1}^{i, j}$ using instruments correlated with the size of the total diaspora in 1990 but uncorrelated to

\footnotetext{
${ }^{9}$ In contrast, when using logistic transformation of the shares, there is no explicit constraint to account for in the estimation process.

${ }^{10}$ An explicit test assessing the relevance of the SURE estimation compared to OLS estimation strongly supports the SURE estimates. Failure to account for the correlation between the $\epsilon_{t, g, h}^{i, j}$ leads to quite different results.
} 
migration flows between 1990 and 2000.

In this paper, we use two instruments. The first one has been proposed by Beine et al. (2009). It captures guest workers programs implemented to attract new migrants to work in some specific industries in the aftermath of the Second World War. These guest workers agreements were conducted on a bilateral basis (for instance between Mexico and the US, Italy and Belgium) and most of those came to an end during the Seventies. Therefore, they are good predictors of the push and pull factors that led to the building of the total diaspora observed in 1970 in a set of destination countries. Since those programs ended in the 70's, they are not supposed to influence the recent flows of migrants. ${ }^{11}$ The second instrument is simply the size of the total diaspora observed in 1960. This instrument complements the use of the first instrument to predict the diaspora observed in 1990, especially in destination countries that did not implement any guest worker program. The use of that instrument raises the quality of adjustment of the first stage regression in the IV procedure with respect to the use of the guest workers programs as a single instrument. ${ }^{12}$ Therefore it minimizes the risk of weak instrumentation associated to the use of a single instrument.

An additional difficulty is to combine SURE estimation and instrumentation. We use two alternative methods. In the first method, we use SURE estimation with the predicted values of $D_{t-1}^{i, j}$ based on the first stage regression involving the two instruments. As an alternative, we can use 3-stage least squares, i.e. the estimation of the SURE system with an additional equation which is the first stage equation of the IV procedure. This method has the advantage of correcting for the estimated standard errors of the parameters. For the sake of robustness, we provide the estimation of system (8-11) using the three alternative estimation methods : (i) SURE, (ii) SURE with predicted values of $D_{t-1}^{i, j}$ and (iii) 3-stage least squares.

\subsection{Benchmark regression results}

Tables 1, 2 and 3 report the results of model(8-11) for the three estimation methods.

A first important result of the analysis is that the three alternative methods yield similar results in many respects. First of all, we find that the three estimation methods yield similar estimates of the elasticity of migration shares with respect to the diaspora. The elasticity is found to be negative for skilled migrants and positive for unskilled migrants. This result is in line with Beine et al. (2009) and McKenzie and Rapoport (2009). Also,

\footnotetext{
${ }^{11}$ See details on that instrument in Beine et al. (2009)

${ }^{12}$ To illustrate, the F-stat of the first stage regression involving the IV estimation of the proportion of the flow of unskilled men amounts to 50.43 with only one instrument and to 321.77 with both instruments.
} 
it is found that distance tends to affect the proportion of skilled men vs less skilled men while it does not affect, at least in a linear way, the proportion of women of each type. These results are found with SURE estimates, either with or without an explicit account of the possible endogeneity of the diaspora. Therefore, while it is important to instrument diasporas, the results are not affected by the assumption regarding the correlation between the diaspora and the error term. In contrast and not surprisingly, the results strongly support the need to account for the correlation between error terms across the 4 equations. Unreported results of IV estimates obtained equation by equation suggest that the results are quite different whether SURE is used or not. The Breusch-Pagan tests of the null hypothesis of independent error terms across equation is strongly rejected. ${ }^{13}$

Coming to the economic interpretation of the estimates, two main comments are in order. First, sensitivities of the migrants' proportion to the diaspora are strikingly different across education levels. Actually, in line with the existing literature, we find that networks favor the migration of less skilled rather than skilled migrants. Diasporas are therefore a strong selection device. Interestingly, diaspora effects do not seem to differ between genders for the same education level: less skilled (resp. skilled) women seem to be affected in the same way as less skilled (resp. skilled) men by the presence of a diaspora. In other terms, the estimation results support the validity of $H_{0,1}$ and $H_{0,2}$. As rationalized in the theoretical background, the diaspora effect might be disentangled into a component related to migration policy (the family reunification channel) and the impact of the network on migration costs. Since migration policy is not gender specific, we find that the impact on migration costs does not differ across genders. This contrasts with some findings of the existing literature such as those of Davis and Winters (2001) or Curran and Rivero-Fuente (2003). This suggests that failure to account for differences of educational level across genders might lead to misleading results regarding the difference of sensitivities to some determinants of international migration between women and men. In order to further strengthen this statement, Table 4 reports the results of an explicit testing procedure on the diaspora elasticities. The null hypotheses is that for a given education level, the diaspora elasticities are equal between men and women. For all the estimation methods and for both education levels, we find that the null hypotheses hypothesis cannot be rejected. Estimated $p$-values are well above the usual significance levels, even when using conservative ones.

\footnotetext{
${ }^{13}$ Note that since we use logistic transformations of the proportion of each category of migrants, we do not have to account for the explicit constraints that proportions of migrants sum up to 1.
} 
Table 1. SURE Estimation of diaspora effects

\begin{tabular}{lllll}
\hline & unskilledMAL & skilledMAL & skilledFEM & unskilledFEM \\
\hline ldiasp & & & & \\
& $0.049^{* * *}$ & $-0.082^{* * *}$ & $-0.101^{* * *}$ & $0.0589^{* * *}$ \\
ldist & $(0.011)$ & $(0.010)$ & $(0.010)$ & $(0.010)$ \\
& $-0.100^{* * *}$ & $0.095^{* * *}$ & 0.028 & -0.015 \\
colony & $(0.0354)$ & $(0.032)$ & $(0.032)$ & $(0.034)$ \\
& 0.061 & 0.024 & -0.047 & 0.070 \\
comlang_off & $(0.094)$ & $(0.085)$ & $(0.085)$ & $(0.091)$ \\
& $-0.249^{* * *}$ & $0.206^{* * *}$ & $0.253^{* * *}$ & $-0.119^{* * *}$ \\
shengen & $(0.061)$ & $(0.055)$ & $(0.055)$ & $(0.059)$ \\
& $-0.364^{* * *}$ & $0.770^{* * *}$ & $0.562^{* * *}$ & $-0.512^{* * *}$ \\
\hline origin FE & $(0.126)$ & $(0.115)$ & $(0.115)$ & $(0.122)$ \\
destination FE & yes & yes & yes & yes \\
\hline \hline & yes & yes & yes & yes \\
Obs & & & & \\
RMSE & 2389 & 2389 & 2389 & 2389 \\
Chi2 & 0.738 & 0.672 & 0.671 & 0.716 \\
p-value & 1639.58 & 2118.12 & 3154.68 & 1652.71 \\
R-squared & 0.0000 & 0.0000 & 0.0000 & 0.0000 \\
\hline & 0.4070 & 0.4699 & 0.5691 & 0.4089 \\
\hline
\end{tabular}

Breusch-Pagan test:

$\operatorname{chi} 2(6)=2123.37(0.00)$

${ }^{*}$ Significant at the $10 \%$ level ${ }^{* *} 5 \%$ level ${ }^{* * *} 1 \%$ level

Standard errors in par. 
Table 2. Combined SURE and IV estimation of diaspora effects

\begin{tabular}{lllll}
\hline & unskilledMAL & skilledMAL & skilledFEM & unskilledFEM \\
\hline ldiasp & & & & \\
& & & & \\
ldist & $(0.025 *$ & $-0.096^{* * *}$ & $-0.111^{* * *}$ & $0.086^{* * *}$ \\
& $-0.097^{* *}$ & $(0.023)$ & $(0.023)$ & $(0.024)$ \\
colony & $(0.043)$ & $\left(0.078^{*}\right.$ & 0.020 & 0.014 \\
& 0.079 & 0.033 & $(0.039)$ & $(0.042)$ \\
comlang_off & $(0.096)$ & $(0.088)$ & -0.072 & 0.039 \\
& $-0.245^{* * *}$ & $0.200^{* * *}$ & $(0.088)$ & $(0.093)$ \\
shengen & $(0.061)$ & $(0.055)$ & $(0.055)$ & $-0.120^{* * *}$ \\
& $-0.326^{* * *}$ & $0.718^{* * *}$ & $0.525^{* * *}$ & $-0.059)$ \\
& $(0.121)$ & $(0.110)$ & $(0.111)$ & $(0.117)$ \\
\hline origin FE & & & & \\
destination $\mathbf{F E}$ & yes & yes & yes & yes \\
\hline \hline & yes & yes & yes & yes \\
Obs & & & & \\
RMSE & 2471 & 2471 & 2471 & 2471 \\
Chi2 & 0.741 & 0.677 & 0.678 & 0.718 \\
p-value & 1616.37 & 2079.81 & 3069.71 & 1638.54 \\
R-squared & 0.0000 & 0.0000 & 0.0000 & 0.0000 \\
\hline
\end{tabular}

Breusch-Pagan test: $\operatorname{chi} 2(6)=2279.14(0.00)$

* Significant at the $10 \%$ level ${ }^{* *} 5 \%$ level ${ }^{* * *} 1 \%$ level Standard errors in par. 
Table 3. Three Stage Least Squares estimation of diaspora

\begin{tabular}{lclll}
\hline & unskilledMAL & skilledMAL & skilledFEM & unskilledFEM \\
\hline \multirow{2}{*}{ ldiasp } & & & & \\
& & & & \\
ldist & $\left(0.024^{*}\right.$ & $-0.104^{* * *}$ & $-0.121^{* * *}$ & $0.100^{* * *}$ \\
& $-0.094^{* *}$ & $(0.025)$ & $(0.025)$ & $(0.026)$ \\
colony & $(0.046)$ & $(0.042)$ & $(0.042)$ & 0.035 \\
& 0.054 & 0.056 & -0.017 & 0.006 \\
comlang_off & $(0.101)$ & $(0.092)$ & $(0.092)$ & $(0.098)$ \\
& $-0.252^{* * *}$ & $0.218^{* * *}$ & $0.264^{* * *}$ & $-0.143^{* *}$ \\
shengen & $(0.062)$ & $(0.057)$ & $(0.057)$ & $(0.061)$ \\
& $-0.364^{* * *}$ & $0.774^{* * *}$ & $0.566^{* * *}$ & $-0.521^{* * *}$ \\
& $(0.126)$ & $(0.115)$ & $(0.115)$ & $(0.123)$ \\
\hline origin FE & & & & yes \\
destination FE & yes & yes & yes & yes \\
\hline \hline & yes & yes & yes & \\
Obs & & & & 2389 \\
RMSE & 2389 & 2389 & 2389 & 0.719 \\
Chi2 & 0.738 & 0.672 & 0.672 & 1627.34 \\
p-value & 1623.56 & 2065.29 & 3073.88 & 0.0000 \\
R-squared & 0.0000 & 0.0000 & 0.0000 & 0.4052 \\
\hline \hline
\end{tabular}

* Significant at the $10 \%$ level ${ }^{* *} 5 \%$ level ${ }^{* * *} 1 \%$ level

Standard errors in par.

Table 4. Testing for different diaspora elasticities across gender

\begin{tabular}{llll}
\hline & SURE & SURE (IV) & 3SLS \\
\hline Skilled & 0,25 & 0,37 & 0,38 \\
Unskilled & 0,36 & 0,27 & 0,27 \\
& & & \\
\hline \hline
\end{tabular}

p-value of test reported in the table

null hypothesis:equal diaspora elasticities

Another interesting finding concerns the sensitivity to distance. Distance is a good proxy here for the variables affecting directly migration costs and those unrelated to networks. For all estimation methods, we find that distance is a powerful selection device in terms of skills for men. This results is in line with the existing macro literature (Beine et al., 2009). 
Nevertheless, we do not find any effect of distance for women, whether educated or not. This suggests that in the choice of destination, other determinants will affect women's choice so that those determinants will undermine a linear relationship between migration choices and distance. Of course, this does not mean that distance will not affect the choice of destination for women in an unconditional way however. Nevertheless, in some cases, distance will not be the driving force of the migration choice of women. Factors such as security at destination or lack of discrimination against women at destination might lead to other preferred choices. ${ }^{14}$ Such a result is in line with the concept of biological vulnerability associated to female migration (see Lim and Oishi, 1996; Phizacklea, 1983).

Regarding the other variables, we find that colonial links do not affect migration flows or their composition. This result is in line with those obtained by Beine et al. (2009). Colonial links are indeed very related to the existing diaspora. Those links played an important role in the past, after the acquisition of independence obtained by a lot of developing countries in the 50's and 60's. Their impact on the initial migration flows is not to question. As time passes by, most new migrants are more affected by the existing diaspora rather than past colonial links. In other words, this can explain why colonial links have strong predictive power in stock models (Grogger and Hanson, 2009) but not in flow models accounting for the diaspora effects like ours.

Second, we find that a common official language tends to raise the proportion of skilled migrants at the expense of less skilled ones. This holds for women and men. This result is in line with the transferability of skills hypothesis (Chiswick, 1979; Chiswick and Miller, 2007). Linguistic proficiency is mostly needed in skilled rather than unskilled professional occupations. This is in line with the estimation results of Beine et al. (2009). Our results show that this effect holds regardless the gender of the new migrants.

Third, we find that the Shengen agreement is associated with skilled migration. This result should be interpreted with caution. Shengen agreement applies only to wealthy European countries and therefore might be seen also as a proxy of migration between rich countries. It reflects the fact that the free migration regime within the European Union favored the mobility of skilled rather than less skilled people.

\footnotetext{
${ }^{14}$ For instance, suppose that a European woman has the choice between migration to some (seemingly) dangerous US city and some (seemingly) safe Australian city, with other similar determinants (wages, amenities, job opportunities) between the two destinations. It might be the case that in spite of the additional migration cost, this woman might favour the Australian destination for security concerns.
} 


\subsection{Robustness Checks}

\subsubsection{Instrumentation}

In the previous estimation procedure, we paid attention to the possible correlation between the existing diaspora and the error term. This potential correlation is due to the failure to account for the influence of some unobservable bilateral factors affecting the stock and the flows of migrants. As a result, we instrumented the existing diaspora, using the stock of migrants in 1960 and the dummy for guest workers programs implemented after WW2. Actually, those instruments might be considered on a theoretical basis as truly exogenous instruments with respect to the migration flows between 1990 and 2000. Nevertheless, the Hansen overidentification test of the IV regressions suggests that some correlations might be too high. The last row of Table 5 reports the results for the overidentication tests The p-values of the Hansen overidentification tests in the 4 equations (the null hypothesis being zero correlation between the instruments and the error term are respectively $0.43,0.00$, 0.08 and 0.09 . This suggests that the use of the 2 instruments is potentially misleading for the estimation of the proportion of skilled men. ${ }^{15}$ This might shed some doubt on the results of the IV and 3SLS estimation procedures. In order to test the robustness of the results, we also consider 3SLS estimation with only one instrument, namely the size of the diaspora in 1960. The results over the exactly identified setting are reported in Table 6 in Appendix A. Not surprisingly, the F-test of the first stage equation suggest that this instrument is a strong instrument of the diaspora.

Two comments are in order. First, the results regarding the effects of the diaspora are very similar with respects to those obtained with two instruments. We observe the same pattern in the results, i.e. the positive impact for less skilled migrants and the negative impact on the proportion of skilled migrants. Furthermore, like in the benchmark results with two instruments, we do not find different sensitivities between women and men for a given education level, although the difference in the elasticities between unskilled men and unskilled women tends to slightly increase. Second, with respect to distance, our main finding remains valid, although in a less strong way. We find that female migration choices are not directly affected by distance. For men, we find a strong negative relationship for unskilled migrants. The positive impact of distance on the proportion of skilled male migrants becomes insignificant at the 10 percent level.

\footnotetext{
${ }^{15}$ Actually, the overidentification test of the IV regressions is an indirect test of the relevance of the instruments in the 3SLS estimations since the IV procedure is strongly rejected due to correlation between the error terms of the 4 equations. Nevertheless, we use them as a criterion for the validity of our instrument set with respect to the exclusion restrictions.
} 
Table 5. Testing for the quality of instruments in the overidentified setting

Endogenous variable:

lagged diaspora

\begin{tabular}{lllll}
\hline & unskilled MAL & skilled MAL & unskilled FEM & skilled FEM \\
\hline First Stage F-stat & 261.98 & 295.28 & 259.07 & 264.29 \\
& $(0.00)$ & $(0.00)$ & $(0.00)$ & $(0.00)$ \\
\hline \hline Kleibergen-Paap stat. & 261.979 & 295.276 & 259.074 & 264.289 \\
Hansen J statistic & 0.602 & 17.372 & 2.877 & 7.054 \\
P-value & $(0.438)$ & $(0.00)$ & $(0.08)$ & $(0.09)$ \\
\hline \hline
\end{tabular}

\subsubsection{Analyzing proportions}

In the benchmark regression analysis, we have so far used logistic transformations of the proportions of each type of migrants. As emphasized before, the logistic transformation allows to account for the non standard distributions associated to bounded variables such as the proportions. Nevertheless, since our theoretical framework yields predictions in terms of proportions rather their logistic transforms, it might be desirable to carry out a similar statistical analysis in order to assess the influence of logistic transformation on the key results. This implies to reestimate model (8-11) using $P_{t, g, h}^{i, j}$ rather than $S_{t, g, h}^{i, j}$.

Using proportions rather their logistic transformations implies a different estimation strategy. In that case, unlike with logistic transforms, one has to account for the fact that the sum of $P_{t, g, h}^{i, j}$ is equal to one. This constraint has to be accounted for in the estimation strategy. This problem has been tackled in the estimation of almost ideal demand system (AIDS) in which the determinants of expenditures shares are investigated (see for instance Deaton and Muellbauer, 1980). Basically, this implies to leave out the fourth equation and to recover the elasticities of the fourth equation as a residual outcome from the constraint. The choice of the equation left out of the estimation is irrelevant. More specifically, the constraint implies that $\beta_{m l}+\beta_{f l}+\beta_{m u}+\beta_{f u}=0$.

Appendix A1 report the estimation of the system estimated on proportions. Each table presnet the results leaving out one particular equation. The results are obtained using 3SLS estimation with the same set of instruments as in the benchmark estimation. From Tables 6-9, we conduct wald tests on the two key hypothesis, namely $H_{0,1}: \beta_{m u}=\beta_{f u}$ and $H_{0,2}: \beta_{m l}=\beta_{f l}$. We fail to reject both hypothesis at conventional significance levels. The p-value associated to the first hypothesis involving skilled migrants amounts to 0.78 . The corresponding p-value for the second hypothesis involving unskilled migrants amounts to 
0.27. This supports the robustness of our results obtained on the logistic transformations of the proportions of migration flows.

\subsubsection{Female specific determinants}

The previous results regarding the impact of distance suggest that other specific determinants might affect the migration choices of women. In this section we introduce some potential female specific determinants in equations governing female migration. Since our regressions include fixed effects for origins and destinations, it is important to notice that additional determinants have to be bilateral. Factors related to the stance of discrimination or security levels in the destination country are already implicitly captured in the regression. This allows to assess the robustness of our previous results.

We consider the following variable thought to assess the attractiveness of the destination (with respect to the origin country) in terms of female political rights. We build a variable based on the year in which women were allowed to vote for the first time at destination and at the origin. We take the difference between the year at destination and at origin. Therefore, a lower value indicates that the destination country is more progressive towards female political rights, compared to the origin country ${ }^{16}$.

The estimation results are reported in Appendix A. We find that the more progressive is the destination compared to the origin, the higher is the proportion of skilled female and the lower is the proportion of less skilled females. This result is consistent with the fact that skilled migrants are more involved in political activities and more interested by political representation or participation than less skilled migrants. Also, extending the specification with this additional determinant does not change the main pattern of the results: (i) diaspora effects are different across education levels but not across gender and (ii) distance affects male migration choices but not those of women, regardless the education level. ${ }^{17}$

\footnotetext{
${ }^{16}$ This indicator is in line with the level of democracy of the country. The correlation between the difference in female suffrage and democratic attainment is negative and equal to 0,2824. Data for democracy are from Kaufmann D., A. Kraay, and M. Mastruzzi. (2003). ' Governance Matters III: Governance Indicators for 1996-2002.' Policy Research Working Paper 3106. World Bank, Washington, D.C.

${ }^{17}$ The main results are also confirmed using an adjusted value of the ratio in female suffrage. This adjustment account for cases where women are theoretically supposed to have been able to vote for a long time while the general level of democracy is obviously low. For those countries, there is thus a high level of discrepancy between theoretical and practical rights. To correct for that, we proceeded according to the following steps. We first identified those presumably critical countries for which the year in which females started to vote is too 'low' (i.e. less recent in terms of time) with respect to the level of democracy (i.e. Afghanistan, Burma, Cuba, Hong Kong, Macao, East Timor, Equatorial Guinea, Iraq, Israel, Libya, Nauru, Sudan, Syria, Turkemenistan, Tuvalu). We then replaced the suffrage ratios belonging to those
} 


\subsubsection{Educational and gender structure of the diaspora}

So far, we have assumed that the impact of the diaspora is the same regardless of its structure. Two types of characteristics might be considered. In line with the microeconometric literature on the impact of migration network, a first type of structure concerns the proportion of women and men in the existing diaspora. For instance Davis and Winters (2001) show that female networks have a strong influence on the choice of female migrants in terms of the destination. Curran and Rivero-Fuentes (2003) find support in favour of symmetric effects in terms of gender, i.e. female (resp. male) networks affecting more female (resp. male) migration.

The second feature is the skill composition of the diaspora. It might be the case that the skill composition of the diaspora will affect the impact of such diaspora in terms of decreased migration costs. For instance, skilled migrants might provide more precise information to new migrants in terms of administrative procedures, job opportunities, ... In turn, this impact might be lower of higher on skilled and unskilled migrants.

One modeling approach is to break down the existing diaspora between the skilled and unskilled parts on the one hand and/or between the female and the male components on the other hand is one. Unfortunately, in a cross-section set-up like ours, this leads to a very strong collinearity between the various networks, which in turn precludes a sound estimation of the effect of the diasporas. An alternative approach is to include the total diaspora along with some ratios characterizing its composition. A first possibility is to augment system specification (8-11) with the sex ratio defined as the number of men divided by the number of women in the diaspora observed in 1990. A second possibility is to include the selection ratio as defined by Grogger and Hanson (2009) and Beine et al. (2009) which takes the ratio of skilled migrants over unskilled migrants. In line with those authors, we take the ratio of the number of migrants with tertiary education over the number of migrants with primary education in the diaspora observed in 1990. Results are reported in Tables 8 and 9 in Appendix A. Table 8 gives the 3SLS estimates of model (8-11) in which the sex ratio is introduced. Table 9 gives the same results with the selection ratio instead of the sex ratio.

The extension of the benchmark results to the inclusion of the structure of the diaspora, either in terms of gender or in terms of skill yields the following results. With respect to the gender structure, we do not find any additional impact of the gender structure on the proportions of each category of migrants. The coefficients of the sex ratio are obviously insignificant at usual significance levels. Furthermore, our main results remain virtually identical compared to the benchmark regressions.

countries with the highest value (meaning higher than 1) of the original distribution. 
With respect to the skill structure, things are slightly different. We find that the skill structure has an influence on the selection of migrants. We find that the more educated is the existing diaspora, the higher (resp.) is the proportion of skilled (resp. less skilled) migrants. This result suggests that the network effect might be higher for migrants with the same level of education. This might be related to the fact that the informational value of the network depends on the degree of matching between new and old migrants. This holds regardless the gender of those migrants. Introducing the skill ratio does not change the main results of our analysis. Nevertheless, some results are slightly different, such as the diaspora effect on the flow of unskilled male migrants which becomes insignificant (the p-value is equal to 0.117). Nevertheless, one should take those results with some caution. Another interpretation of the significance of the skill ratio is that there is a case for endogeneity of the ratio it-self. Indeed, like for the diaspora variable, the selection ratio might be correlated with the error term through omitted variables that would jointly affect the proportions of migrants and the skill composition of the stocks. This raises the need to instrument the ratio. However, finding suitable instruments for it is not straightforward and beyond the scope of this paper. ${ }^{18}$

\subsubsection{Alternative definition of skilled migrants}

The classification of migrants into skilled and less skilled workers rests on a choice concerning the level of education above which people are considered skilled. In the brain drain literature, skilled workers are often considered as those with tertiary education level. This explains the choice we made in the benchmark regressions. For the sake of robustness, one might consider another classification, including migrants with secondary educational achievement in the category of skilled workers instead of less skilled ones.

Table 10 in Appendix A provides the results with the alternative classification of workers. Skilled migrants are those with tertiary and secondary education levels while less skilled ones are only those with primary education (or less). The results are very similar to those obtained with the benchmark classification in terms of skills. In particular, the diaspora effects are found to be similar across the various categories of migrants. We find a slightly different result for the impact of distance in the sense that distance is not found to affect unskilled male migrants. Nevertheless, while distance is a strong selection device for skilled men, it does not affect the proportion of skilled and unskilled women, like in our benchmark results. All in all, those findings suggest that our benchmark results are

\footnotetext{
${ }^{18}$ Actually, we tried to use the set of instruments used for the lagged diaspora. Since we have two potential instruments, this would lead to an exactly identified setting in that case. Nevertheless, the guest worker agreement and the stock of migrants in 1960 did not turn out to be correlated with the skill ratio.
} 
robust to the definition of skilled and unskilled migrants, to the structure of the diaspora, to the instrumentation procedure and to the introduction of specific determinants of female migration.

\section{Conclusion}

In this paper, we have analyzed the sensitivity to networks for male and female migrants. The main contribution of this paper is that we account for both the gender and the educational dimensions of the migrants. Failing to account for the educational attainment of the migrants is likely to lead to problems in the identification of factors that drive differences in propensity to migrate if migration patterns are unbalanced. The migration patterns might be unbalanced between men and women, between skilled and less skilled or in both dimensions. In particular, for countries in which women are much less educated than men, failing to account for the educational level might lead to ascribe a spurious role to gender.

Using a new release of the Docquier, Lowell and Marfouk (2009) database on international migration by gender and by education attainment, we estimate the role of networks and other determinants of migration such as distance on the proportion of each type of migrant. In line with the recent literature, we show that networks have heterogeneous effects between skilled and unskilled migrants. In contrast, the sensitivity to network is statistically identical between men and women for each skill level. The results are robust to the definition of skilled workers, to the estimation technique, to the adopted specification, to the instrumentation procedure and to the structure of the diaspora it-self. In contrast, regarding the literature on the determinants of international migration, we find a different role for some other factors such as distance. 


\section{References}

- Agnew, J.R., L.R. Andersen, J.R. Gerlach, and L.R. Szykman, (2008), 'Who Chooses Annuities? An Experimental Investigastion of the Role of Gender, Framing, and Defaults', American Economic Review, Vol. 98, N.2, 418-422

- Basok, T., (2000), 'He Came, He Saw, He ... Stayed. Guest Worker Programmes and the Issue of Non-Return', International Migration Vol. 38 (2) 2000

- Beine, M., F. Docquier, and H. Rapoport (2007), Measuring International Skilled Migration: A New Database Controlling for Age of Entry, the World Bank Economic Review, 21, 249-254.

- Beine, M., F. Docquier, and C. Ozden, (2009), 'Diasporas', forthcoming in the Journal of Development Economics.

- Blackden M., S. Canagarajah, S. Klase and D. Lawson (2006). 'Gender and growth in Sub-Saharan Africa.' UNU-WIDER Research Paper n. 2006-37

- Bohning, W.R., (1974), 'Immigration Policies of Western European Countries', International Migration Review, Vol. 8, No. 2, Special Issue: Policy and Research on Migration: Canadian and World Perspectives (Summer, 1974), 155-163.

- Borgas, G., (1987), 'Self-Selection and the Earnings of Immigrants, American Economic Review, 77 (4), 531-533.

- Borghans, L., B.H.H. Golsteyn, J.J. Heckman, and H. Meijers, (2009), 'Gender Differences in Risk Aversion and Ambiguity Aversion', IZA Discussion Paper, N. $3985,1-17$

- Boyd, M. (1989), 'Family And Personal Networks In International Migration: Recent Developments and New Agendas', International Migration Review, 23(3), 638670

- Carrington W.J., Enrica Detragiache, Tara Vishwanath, (1996), 'Migration with Endogenous Moving Costs', The American Economic Review, Vol. 86, No. 4, 909930

- Castles, S., (1986), 'The Guest-Worker in Western Europe - An Obituary', International Migration Review, Vol. 20, No. 4, Special Issue: Temporary Worker Programs: Mechanisms, Conditions, Consequences (Winter, 1986), 761-778 
- Cerrutti, M. and D.S. Massey (2001). 'On the Auspices of Female Migration from Mexico to the United States.' Demography, 38 (2), 187-200.

- Chen, N., P. Conconi, and C. Perroni (2007). 'Intergenerational Mobility of Migrants: Is There a Gender Gap?', Warwik Economic Research Papers N.815, pp. $1-29$

- Chiswick, B.R. (1978), The Effect of Americanisation on the Earnings of Foreignborn Men, Journal of Political Economy, 86 (5), pp. 897-921.

- Chiswick, B.R. and Miller P. (2007), 'The International Transferability of Immigrants' Human Capital Skills', IZA Discussion Paper, N. 2670

- Clair, G., G. Gaullier, Th. Mayer and S. Zignago (2004), 'A note on CEPII's distances measures., Explanatory note', CEPII, Paris.

- Cobb-Clark, D.A., (1993), 'Immigrant Selectivity and Wages: The Evidence for Women', American Economic Review, Vol. 83, N. 4, 986-993

- Cohen, A. and A. Razin (2008), "Skill composition of migration and the generosity of the welfare state: free vs. policy-restricted migration", Mimeo., Tel-Aviv University.

- Coulombe, S. and J-F. Tremblay (2006).'Literacy and growth.' Topics in macroeconomics 6(2), article 4 .

- Curran S.R. and E. Rivero-Fuentes, (2003), 'Engendering migrant networks: The case of Mexico migration.' Demography 40 (2)

- Davis, B., and Winters P., (2001), 'Gender, Networks and Mexico-US Migration', Journal of Development Studies, N.38, 1-22

- Diner, H. R. 1983. Erin's Daughters in America: Irish Immigrant Women in the Nineteenth Century. Baltimore, Md: Johns Hopkins Press.

- Docquier, F., and E. Lodigiani, (2009), 'International Migration and Business Networks', Open Economies Review, forthcoming

- Docquier F., O. Lohest and A. Marfouk, (2007), 'Brain drain in developing countries.' World Bank Economic Review 21, 193-218

- F. Docquier, A. Marfouk, 'International migration by educational attainment (19902000) - Release 1.1', In C. Ozden and M. Schiff (eds). International Migration, Remittances and Development, Palgrave Macmillan: New York (2006), chapter 5. 
- Docquier F., B. L. Lowell, and A. Marfouk, (2009), 'A gendered assessment of the brain drain', Population and Development Review, 35 (2), 297-322

- Docquier, F., A. Marfouk, S.Salomone, and K. Sekkat, (2009), 'Are skilled women more migratory than skilled men?', UCL Discussion Paper, N. 2009021, 1-30

- Dollar, D. and R. Gatti (1999). 'Gender inequality, income and growth - Are good times good for women?' Policy Research Report on Gender and Development, Working paper series, n.1, World Bank.

- Dumont, J.C., J.P. Martin and G. Spielvogel, (2007). 'Women on the move: the neglected gender dimension of the brain drain.' IZA Discussion Paper, n. 2920

- European Commission, (2003), 'COUNCIL DIRECTIVE 2003/86/EC of 22 September 2003 on the right to family reunification', Official Journal of the European Union, pp. $1-7$

- Evans, W.N., W.E. Oates and R.M. Schwab, (1992), 'Measuring Peer Group Effects: A Study of Teenage Behavior', Journal of Political Economy 100 (5), 966-91

- Gao, T., (2003), 'Ethnic Chinese Networks and International Investment: Evidence from Inward FDI in China', Journal of Asian Economics, 14, 611-629

- Grogger, J and G.H. Hanson, (2009), 'Income Maximisation and the selection and sorting of international Migrants', forthcoming in Journal of Development Economics.

- Hondagneu-Sotelo, P., and C. Cranford, (1999), 'Gender and Migration', Handbook of the Sociology of Gender, Ed. J.S.Chafetz. New York: Kluwer Academic/Plenum Publishers

- Jasso G., and M.R. Rosenzweig, (1986), 'Family Reunification and the Immigration Multiplier: U.S. Immigration Law, Origin Country Conditions, and the Reproduction of Immigrants', Demography, Vol. 23, N. 3, pp. 291-311

- Johnson, N. (1949), 'Systems of Frequency Curves Generated by Methods of Translation', Biometrika,36, 149-176

- Kaufmann D., A. Kraay, and M. Mastruzzi. (2003). Governance Matters III: Governance Indicators for 19962002. Policy Research Working Paper 3106. World Bank, Washington, D.C. 
- Klasen, S. (1999). 'Does gender inequality reduce growth and development? Evidence from cross-country regressions.' Policy Research Report on Gender and Development, Working paper series, n.7, World Bank.

- Knowles, S., P.K. Lorgelly, and P.D. Owen, (2002), 'Are educational gender gaps a brake on economic development? Some cross-country empirical evidence', Oxford Economic Papers, 54, 118-149

- Kremer, M. and S. Watt (2006), the Globalization of Household Production, Weatherhead Center For International Affairs, Harvard University.

- Lim, LL and N. Oishi, (1996), 'International labor migration of Asian women: distinctive characteristics and policy concerns', Asian and Pacific Migration Journal, Vol. 5(1), 85-116.

- Mahler, S.J., and P.R. Pessar, (2006), 'Gender Matters: Ethnographers Bring Gender from the Periphery toward the Core of Migration Studies', International Migration Review, Vol.40, N.1, 27-63

- Manski, Ch.F, (1993), 'Identification of Endogenous Social Effects: The Reflection Problem' Review of Economic Studies 60 (3), 531-42

- Martin, P.L., (2000), 'Managing Labor Migration: Temporary Worker Programs for the 21st Century', ILO Publications, Geneva, September 2003

- Massey, D.S., J. Arango, G. Hugo, A. Kouaouci, A. Pellegrino and J. E. Taylor (1993), 'Theories of international migration: Review and Appraisal', Population and Development Review 19(3), 431-466

- McDowell, L., (2003), 'Workers, migrants, aliens or citizens?State constructions and discourses of identity among post-war European labour migrants in Britain', Political Geography 22 (2003) 863886

- McKenzie, D., and H. Rapoport, (2009), 'Self-selection patterns in Mexico-US migration: the role of migration networks', Review of Economics and Statistics, forthcoming.

- Morrison, A.R., M. Schiff and M. Sjöblom (2007), 'The international migration of women', Palgrave McMillan.

- Munshi, K. (2003), 'Networks In The Modern Economy: Mexican Migrants in The U.S. Labor Market' The Quarterly Journal of Economics 118(2), 549-599 
- OECD, (2000), 'Trends in International Migration', 1-24

- Pedersen P.J., M. Pytlikova and N. Smith, (2008), 'Selection or Network Effects? Migration Flows into 27 OECD Countries, 1990-2000,' European Economic Review, forthcoming.

- Phizacklea, A., (1983), 'One Way Ticket', published by Routledge and Kegan Paul

- Rapoport, H., and M. Kugler, (2006), 'Skilled Emigration, Business Networks and Foreign Direcy Investment', CESifo Working Paper Series N.1455

- Rauch, J., (2003), 'Diasporas and Development: Theory, Evidence and Programmatic Implications', Department of Economics, University of California at San Diego

- Rauch, J., and A. Casella, (1998), 'Anonymous Market and Group Ties in Internationale Trade', Journal of International Economics, Vol. 58(1), 19-47

- Rauch, J., and V. Trinidade, (2002), 'Ethnic Chines Networks in International Trade', The Review of Economics and Statistics, MIT Press, Vol. 84(1), 116-130

- Ramirez, F.O., J. Soysal and S. Shanahan , (1997), 'The changing logic of political citizenship: cross-national acquisition of women's suffrage rights, 1890 to 1990', American Sociological Review, Vol. 62 (5), 735-745

- Ravenstein E.G., (1885). 'The Laws of Migration.' Journal of the Statistical Society of London 48 (2), 167-235.

- Roy, A.D. (1951), Some Thoughts on the Distribution of Earnings, Oxford Economic Papers, 3, 135-146.

- Ruhs, M., and P. Martin, (2008), 'Numbers vs. Rights: Trade-Offs and Guest Worker Programs',IMR Volume 42 Number 1, 249265

- Schubert, R., M. Brown, M. Gysler, and H.W. Brachinger, (1999), 'Financial Decision Making: Are women Really More Risk-Averse?', American Economic Review, Vol. 89, N.2, 380-385

- Seielstad M.T., E. Minch and L.L. Cavalli-Sforza (1998). 'Genetic evidence for a higher female migration rate in humans.' Nature Genetics 20, 278 - 280.

- UNESCO, (2008), 'Education for all', Global Monitoring Report 2008 
- Wiltshire, R., (1992), 'Implications of transnational migration for nationalism: the Carribean example'. In N. Glick Schiller, L. Basch, and C. Blanc Szanton (eds), Towards a Transnational Perspective on migration: race, class, ethnicity, and nationalism reconsidered (Annals of the New York Academy of Sciences, Vol.645, 175-187. New York: New York Academy of Sciences

- Zlotnik, H. (1990). 'International Migration Policies and the Status of Female Migrants.' International Migration Review, 24 (2), 372-381.

- Zlotnik, H. (1995). 'The South-to-North Migration of Women.' International Migration Review, 29 (1), 229-254. 


\section{Appendix A: Tables of the Robustness Analysis}

\subsection{Appendix $A_{1}$ : Estimation of the impact on proportions}

Table 6 present the estimates of system (8)-(11) on proportions rather than on their logistic transformations. This implies to leave out one of the four equations of the estimation. Table 6-9 present the results leaving out one particular equation. Note that the results are strictly identical regardless of the excluded equation.

Table 6. Excluding unskilled males

\begin{tabular}{llll}
\hline & skilledMAL & skilledFEM & unskilledFEM \\
\hline ldiasp & & & \\
& $-0.0086^{* * *}$ & $-0.0101^{* * *}$ & $0.0108^{* * *}$ \\
ldist & $(0.001)$ & $(0.001)$ & $(0.001)$ \\
& $0.0171^{* * *}$ & 0.0007 & -0.0004 \\
colony & $(0.004)$ & $(0.004)$ & $(0.005)$ \\
& -0.0024 & -0.0111 & 0.0135 \\
comlang_off & $(0.011)$ & $(0.011)$ & $(0.015)$ \\
& $0.0265^{* * *}$ & $0.0253^{* * *}$ & $-0.0161^{*}$ \\
shengen & $(0.007)$ & $(0.007)$ & $(0.009)$ \\
& $0.107^{* * *}$ & $0.052^{* * *}$ & $-0.0970^{* * *}$ \\
\hline origin FE & $(0.015)$ & $(0.015)$ & $(0.022)$ \\
destination FE & yes & yes & yes \\
\hline \hline & yes & yes & yes \\
Obs & & & \\
RMSE & 2389 & 2389 & 2389 \\
Chi2 & 0.0915 & 0.0904 & 0.119 \\
p-value & 2158.21 & 2948.31 & 1937.72 \\
R-squared & 0.0000 & 0.0000 & 0.0000 \\
\hline
\end{tabular}

Breusch-Pagan test:

$\operatorname{chi} 2(3)=1452.907(0.00)$

Significant at the $10 \%$ level ${ }^{* *} 5 \%$ level ${ }^{* * *} 1 \%$ level

Standard errors in par. 
Table 7. Excluding skilled males

\begin{tabular}{|c|c|c|c|}
\hline & unskilledMAL & skilledFEM & unskilledFEM \\
\hline \multirow[t]{2}{*}{ ldiasp } & $0.0079^{* * *}$ & $-0.0101^{* * *}$ & $0.0108^{* * *}$ \\
\hline & $(0.001)$ & $(0.001)$ & $(0.001)$ \\
\hline \multirow[t]{2}{*}{ ldist } & $-0.0174^{* * *}$ & 0.0007 & -0.0004 \\
\hline & $(0.0055)$ & $(0.004)$ & $(0.005)$ \\
\hline \multirow[t]{2}{*}{ colony } & 0.0000 & -0.0111 & 0.013 \\
\hline & $(0.0146)$ & $(0.0115)$ & $(0.051)$ \\
\hline \multirow[t]{2}{*}{ comlang_off } & $-0.0358 * * *$ & $0.0253^{* * *}$ & $-0.161^{*}$ \\
\hline & $(0.009)$ & $(0.074)$ & $(0.009)$ \\
\hline \multirow[t]{2}{*}{ shengen } & $-0.0627^{* * *}$ & $0.0525^{* * *}$ & $-0.097 * * *$ \\
\hline & $(0.0196)$ & $(0.154)$ & $(0.009)$ \\
\hline \multirow{2}{*}{$\begin{array}{l}\text { origin FE } \\
\text { destination FE }\end{array}$} & yes & yes & yes \\
\hline & yes & yes & yes \\
\hline Obs & 2389 & 2389 & 2389 \\
\hline RMSE & 0.1149 & 0.0904 & 0.119 \\
\hline Chi2 & 1901.43 & 2948.31 & 1937.72 \\
\hline p-value & 0.0000 & 0.0000 & 0.0000 \\
\hline R-squared & 0.4432 & 0.5524 & 0.4478 \\
\hline
\end{tabular}

Breusch-Pagan test:

$\operatorname{chi} 2(3)=1321.346(0.00)$

Significant at the $10 \%$ level ${ }^{* *} 5 \%$ level ${ }^{* * *} 1 \%$ level

Standard errors in par. 
Table 8. Excluding unskilled females

\begin{tabular}{llll}
\hline & unskilledMAL & skilledMAL & skilledFEM \\
\hline \multirow{2}{*}{ ldiasp } & $0.0079^{* * *}$ & $-0.0086^{* * *}$ & $-0.0101^{* * *}$ \\
& $(0.001)$ & $(0.0013)$ & $(0.0013)$ \\
ldist & $-0.017^{* * *}$ & $0.0171^{* * *}$ & 0.0007 \\
& $(0.0055)$ & $(0.0043)$ & $(0.004)$ \\
colony & 0.000 & 0.0024 & -0.011 \\
& $(0.014)$ & $(0.0116)$ & $(0.011)$ \\
comlang_off & $-0.358^{* * *}$ & $0.0206^{* * *}$ & $0.0253^{* * *}$ \\
& $(0.009)$ & $(0.0075)$ & $(0.007)$ \\
shengen & $-0.062^{* * *}$ & $0.107^{* * *}$ & $0.0525^{* * *}$ \\
& $(0.019)$ & $(0.015)$ & $(0.154)$ \\
\hline origin FE & yes & yes & yes \\
destination FE & yes & yes & yes \\
\hline \hline & & & \\
Obs & & 2389 & 2389 \\
RMSE & 2389 & 0.0915 & 0.0904 \\
Chi2 & 0.1149 & 2158.21 & 2948.31 \\
p-value & 1901.43 & 0.0000 & 0.0000 \\
R-squared & 0.0000 & 0.4746 & 0.5524 \\
\hline
\end{tabular}

Breusch-Pagan test:

$\operatorname{chi} 2(3)=1327.262(0.00)$

Significant at the $10 \%$ level ${ }^{* *} 5 \%$ level ${ }^{* * *} 1 \%$ level

Standard errors in par. 
Table 9. Excluding skilled females

\begin{tabular}{|c|c|c|c|}
\hline & unskilledMAL & skilledMAL & unskilledFEM \\
\hline \multirow[t]{2}{*}{ ldiasp } & $0.0079 * * *$ & $-0.0086^{* * *}$ & $0.0108^{* * *}$ \\
\hline & $(0.017)$ & $(0.0013)$ & $(0.0018)$ \\
\hline \multirow[t]{2}{*}{ ldist } & $-0.0174^{* * *}$ & $0.0171^{* * *}$ & -0.0004 \\
\hline & $(0.055)$ & $(0.0043)$ & $(0.005)$ \\
\hline \multirow[t]{2}{*}{ colony } & 0.000 & 0.0024 & 0.035 \\
\hline & $(0.0146)$ & $(0.0116)$ & $(0.015)$ \\
\hline \multirow[t]{2}{*}{ comlang_off } & $-0.0358 * * *$ & $0.0265^{* * *}$ & -0.0161 \\
\hline & $(0.0094)$ & $(0.065)$ & $(0.009)$ \\
\hline \multirow[t]{2}{*}{ shengen } & $-0.0627^{* * *}$ & $0.107^{* * *}$ & $-0.097 * * *$ \\
\hline & $(0.0196)$ & $(0.156)$ & $(0.0203)$ \\
\hline \multirow{2}{*}{$\begin{array}{l}\text { origin FE } \\
\text { destination FE }\end{array}$} & yes & yes & yes \\
\hline & yes & yes & yes \\
\hline Obs & 2389 & 2389 & 2389 \\
\hline RMSE & 0.1149 & 0.0915 & 0.119 \\
\hline Chi2 & 1901.43 & 2158.21 & 1937.72 \\
\hline p-value & 0.0000 & 0.0000 & 0.0000 \\
\hline R-squared & 0.4432 & 0.4746 & 0.4478 \\
\hline
\end{tabular}

Breusch-Pagan test:

$\operatorname{chi} 2(6)=1345.199(0.00)$

Significant at the $10 \%$ level ${ }^{* *} 5 \%$ level ${ }^{* * *} 1 \%$ level

Standard errors in par. 


\subsection{Appendix $A_{2}$ : Tables of the Robustness Analysis}

Table 10. Exactly Identified setting

unskilledMAL skilledMAL skilledFEM unskilledFEM

\begin{tabular}{lrrrr} 
ldiasp & $0.048^{*}$ & $-0.116^{* * *}$ & $-0.116^{* * *}$ & $0.110^{* * *}$ \\
& $(0.026)$ & $(0.023)$ & $(0.024)$ & $(0.025)$ \\
ldist & $-0.091^{* *}$ & 0.054 & 0.014 & 0.041 \\
& $(0.044)$ & $(0.040)$ & $(0.040)$ & $(0.042)$ \\
colony & 0.072 & 0.061 & -0.065 & 0.005 \\
& $(0.097)$ & $(0.088)$ & $(0.088)$ & $(0.093)$ \\
comlang_off & $-0.248^{* * *}$ & $0.212^{* * *}$ & $0.266^{* * *}$ & $-0.134^{* *}$ \\
& $(0.061)$ & $(0.055)$ & $(0.056)$ & $(0.059)$ \\
shengen & $-0.327^{* * *}$ & $0.724^{* * *}$ & $0.528^{* * *}$ & $-0.488^{* * *}$ \\
& $(0.121)$ & $(0.110)$ & $(0.111)$ & $(0.117)$ \\
& & & & yes \\
\hline origin FE & yes & yes & yes & yes \\
destination FE & yes & yes & & \\
\hline \hline & & & & \\
Obs & 2471 & 2471 & 2471 & 2471 \\
Chi2 & 1617.16 & 2091.68 & 3071.17 & 1649.61 \\
p-value & $(0.00)$ & $(0.00)$ & $(0.00)$ & $(0.00)$ \\
R-squared & 0.3956 & 0.4584 & 0.5541 & 0.4003 \\
\hline & & & & \\
F-stat first stage: & 479.39 & 564.27 & 500.08 & 488.71 \\
& $(0.00)$ & $(0.00)$ & $(0.00)$ & $(0.00)$ \\
\hline
\end{tabular}

Breusch-Pagan test:

$\operatorname{chi} 2(6)=2271.55(0.00)$

* Significant at the $10 \%$ level ** $5 \%$ level *** $1 \%$ level

Standard errors in par. 
Table 11. Adding the difference in female suffrage

\begin{tabular}{|c|c|c|c|c|}
\hline & unskilledMAL & skilledMAL & skilledFEM & unskilledFEM \\
\hline ldiasp & $\begin{array}{r}0.061^{* *} \\
(0.027)\end{array}$ & $\begin{array}{r}-0.104^{* * *} \\
(0.024)\end{array}$ & $\begin{array}{r}-0.123^{* * *} \\
(0.025)\end{array}$ & $\begin{array}{r}0.108^{* * *} * \\
(0.026)\end{array}$ \\
\hline ldist & $\begin{array}{c}-0.081^{*} \\
(0.047)\end{array}$ & $\begin{array}{c}0.069 * \\
(0.042)\end{array}$ & $\begin{array}{r}0.00 \\
(0.042)\end{array}$ & $\begin{array}{r}0.041 \\
(0.045)\end{array}$ \\
\hline colony & $\begin{array}{r}0.046 \\
(0.101)\end{array}$ & $\begin{array}{r}0.056 \\
(0.092)\end{array}$ & $\begin{array}{r}-0.026 \\
(0.092)\end{array}$ & $\begin{array}{r}0.005 \\
(0.098)\end{array}$ \\
\hline comlang_off & $\begin{array}{r}-0.257^{* * *} * \\
(0.062)\end{array}$ & $\begin{array}{r}0.216^{* * *} \\
(0.057)\end{array}$ & $\begin{array}{r}0.266^{* * *} \\
(0.056)\end{array}$ & $\begin{array}{r}-0.145^{* *} \\
(0.061)\end{array}$ \\
\hline shengen & $\begin{array}{r}-0.370^{* * *} \\
(0.126)\end{array}$ & $\begin{array}{r}0.780^{* * *} \\
(0.115)\end{array}$ & $\begin{array}{r}0.595^{* * *} \\
(0.115)\end{array}$ & $\begin{array}{r}-0.549^{* * *} \\
(0.123)\end{array}$ \\
\hline fem suffrage & & & $\begin{array}{r}-0.344^{* * *} \\
(0.113)\end{array}$ & $\begin{array}{r}0.344^{* * *} \\
0.123\end{array}$ \\
\hline $\begin{array}{l}\text { origin FE } \\
\text { destination FE }\end{array}$ & $\begin{array}{l}\text { yes } \\
\text { yes }\end{array}$ & $\begin{array}{l}\text { yes } \\
\text { yes }\end{array}$ & $\begin{array}{l}\text { yes } \\
\text { yes }\end{array}$ & $\begin{array}{l}\text { yes } \\
\text { yes }\end{array}$ \\
\hline $\begin{array}{l}\text { Obs } \\
\text { Chi2 } \\
\text { p-value } \\
\text { R-squared }\end{array}$ & $\begin{array}{r}2341 \\
1591.96 \\
(0.00) \\
0.4069\end{array}$ & $\begin{array}{r}2341 \\
2002.65 \\
(0.00) \\
0.4664\end{array}$ & $\begin{array}{r}2341 \\
3021.36 \\
(0.00) \\
0.5677\end{array}$ & $\begin{array}{r}2341 \\
1615.08 \\
(0.00) \\
0.408\end{array}$ \\
\hline
\end{tabular}

* Significant at the $10 \%$ level ${ }^{* *} 5 \%$ level *** $1 \%$ level

Standard errors in par. 
Table 12. Adding the gender structure of the diaspora

\begin{tabular}{lclll}
\hline & unskilledMAL & skilledMAL & skilledFEM & unskilledFEM \\
\hline \multirow{2}{*}{ ldiasp } & & & & \\
& $\left(0.0604^{* *}\right.$ & $-0.101^{* * *}$ & $-0.120^{* * *}$ & $0.1032^{* * *}$ \\
ldist & $-0.0862^{*}$ & $(0.0239)$ & $(0.024)$ & $(0.0257)$ \\
& $(0.0458)$ & $(0.0417)$ & $(0.0416)$ & 0.0204 \\
comlang_off & $-0.247^{* * *}$ & $0.224^{*}$ & $0.264^{* * *}$ & -0.131 \\
& $(0.0628)$ & $(0.0572)$ & $(0.057)$ & $(0.0610)$ \\
shengen & $-0.373^{* * *}$ & $0.782^{* * *}$ & $0.593^{* * *}$ & $-0.557^{* * *}$ \\
& $(0.126)$ & $(0.115)$ & $(0.115)$ & $(0.123)$ \\
sexratio & -0.000 & .0000 & -0.000 & .0000 \\
& $(0.000)$ & $(0.000)$ & $(0.000)$ & $(0.000)$ \\
suff2_F & & & $-0.337^{* * *}$ & $0.370^{* * *}$ \\
& & & $(0.113)$ & $(0.123)$ \\
& & & yes & yes \\
\hline origin FE & yes & yes & yes & yes \\
destination FE & yes & yes & & \\
\hline \hline & & & 2322 & 2322 \\
Obs & 2322 & 2322 & 2976.40 & 1594.62 \\
Chi2 & 1565.70 & 1982.83 & $(0.0000)$ & $(0.0000)$ \\
p-value & $(0.0000)$ & $(0.0000)$ & 0.5676 & 0.4111 \\
R-squared & 0.4060 & 0.4684 &
\end{tabular}

* Significant at the $10 \%$ level ** $5 \%$ level *** $1 \%$ level

Standard errors in par. 
Table 13. Adding the educational structure of the diaspora

\begin{tabular}{|c|c|c|c|c|}
\hline & unskilledMAL & skilledMAL & skilledFEM & unskilledFEM \\
\hline ldiasp & $\begin{array}{c}0.0425 \\
(0.0272)\end{array}$ & $\begin{array}{l}-0.0826^{* * *} \\
(0.0246)\end{array}$ & $\begin{array}{l}-0.107^{* * *} \\
(0.0247)\end{array}$ & $\begin{array}{l}0.089 * * * \\
(0.0267)\end{array}$ \\
\hline ldist & $\begin{array}{c}-0.0836^{*} \\
(0.0461)\end{array}$ & $\begin{array}{l}0.0950^{* *} \\
(0.0418)\end{array}$ & $\begin{array}{l}-0.001 \\
(0.0418)\end{array}$ & $\begin{array}{l}0.0207 \\
(0.0451)\end{array}$ \\
\hline comlang_off & $\begin{array}{c}-0.1932^{* * *} \\
(0.0635)\end{array}$ & $\begin{array}{l}0.183^{* * *} \\
(0.0576)\end{array}$ & $\begin{array}{l}0.207^{* * *} \\
(0.057)\end{array}$ & $\begin{array}{l}-0.0876 \\
(0.0621)\end{array}$ \\
\hline shengen & $\begin{array}{c}-0.344^{* * *} \\
(0.125)\end{array}$ & $\begin{array}{l}0.774^{* * *} \\
(0.113)\end{array}$ & $\begin{array}{l}0.560 * * * \\
(0.114)\end{array}$ & $\begin{array}{l}-0.526^{* * *} \\
(0.123)\end{array}$ \\
\hline skillratio & $\begin{array}{c}-0.0423^{* * *} \\
(0.005)\end{array}$ & $\begin{array}{l}0.0250^{* * *} \\
(0.005)\end{array}$ & $\begin{array}{l}0.036^{* * *} \\
(0.005)\end{array}$ & $\begin{array}{l}-0.0295^{* * *} \\
(0.005)\end{array}$ \\
\hline suff2_F & & & $\begin{array}{l}-0.295^{* * *} \\
(0.115)\end{array}$ & $\begin{array}{l}0.325^{* * *} \\
(0.126)\end{array}$ \\
\hline origin FE & yes & yes & yes & yes \\
\hline destination FE & yes & yes & yes & yes \\
\hline Obs & 2303 & 2303 & 2303 & 2303 \\
\hline Chi2 & 1690.41 & 2088.97 & 3118.85 & 1610.89 \\
\hline p-value & $(0.0000)$ & $(0.0000)$ & $(0.0000)$ & $(0.0000)$ \\
\hline R-squared & 0.4250 & 0.4815 & 0.5804 & 0.4155 \\
\hline
\end{tabular}

* Significant at the $10 \%$ level ** $5 \%$ level *** $1 \%$ level

Standard errors in par. 
Table 14. Alternative definition of skilled people

\begin{tabular}{lclll}
\hline & primaryMAL & ter+secMAL & tert+secFEM & primaryFEM \\
\hline & & & & \\
ldiasp & $0.061^{*}$ & $-0.106^{* * *}$ & $-0.072^{* * *}$ & $0.119^{* * *}$ \\
& $(0.0344)$ & $(0.023)$ & $(0.0251)$ & $(0.029)$ \\
ldist & -0.035 & $-0.076^{*}$ & 0.0246 & 0.014 \\
& $(0.058)$ & $(0.039)$ & $(0.042)$ & $(0.049)$ \\
colony & -0.062 & 0.147 & -0.003 & 0.032 \\
& $(0.13)$ & $(0.088)$ & $(0.095)$ & $(0.11)$ \\
comlang_off & $-0.240^{* * *}$ & $0.114^{* *}$ & $0.218^{* * *}$ & $-0.204^{* * *}$ \\
& $(0.082)$ & $(0.056)$ & $(0.060)$ & $(0.0700)$ \\
shengen & $-0.596^{* * *}$ & $0.421^{* * *}$ & $0.513^{* * *}$ & $-0.773^{* * *}$ \\
& $(0.158)$ & $(0.107)$ & $(0.115)$ & $(0.133)$ \\
& & & & \\
\hline origin FE & yes & yes & yes & yes \\
destination FE & yes & yes & yes & yes \\
\hline \hline & & & & \\
Obs & 2116 & 2116 & 2116 & 2116 \\
Chi2 & 1270.96 & 1579.37 & 2031.66 & 1717.25 \\
p-value & $(0.0000)$ & $(0.0000)$ & $(0.0000)$ & $(0.0000)$ \\
R-squared & 0.3753 & 0.4274 & 0.4898 & 0.4480 \\
\hline
\end{tabular}

Breusch-Pagan test:

$\operatorname{chi} 2(6)=1721.411(0.00)$

* Significant at the $10 \%$ level ${ }^{* *} 5 \%$ level ${ }^{* * *} 1 \%$ level

Standard errors in par. 


\section{Appendix B: Data Sources}

- Bilateral migration data as migration flows by gender $\left(S_{t, g, h}^{i, j}\right)$ and migrants' diasporas $\left(D_{t-1}^{i, j}\right)$ come from Docquier, Lowell and Marfouk (2007) dataset as described in section 3. These data are available for 1990 and 2000 and concern 195 countries of orign and 30 countries of destination. The stock of human capital is measured as the proportion of individuals aged 25 and more with tertiary education.

- Data on geographical distance (ldist) between country i and country j are from CEPII (Clair, Gaullier, Mayer and Zignago, 2004)

- Dummies concerning colonial (colony) and linguistic (comlang_off)links are from CEPII (Clair, Gaullier, Mayer and Zignago, 2004)

- The dummy on Shengen agreement concerns the group of twenty-five European countries which have abolished all border controls between each other after June the 14 th 1985 .

- Data on guest workers programs rely upon authors'calculation following Bohning, 1974; Castles, 1986; Basok, 2000; Martin, 2003; McDowell, 2003; Ruhs and Martin, 2008

- Bilateral migration stocks in 1960 are from the World Bank

- Data on female suffrage have been collected by the authors following the Women in Parliament Database compiled by the Inter-Parliamentary Union and available on the Inter-Parliamentary Union Statistical Archive Web site

- Data for democracy are from Kaufmann D., A. Kraay, and M. Mastruzzi. (2003).

' Governance Matters III: Governance Indicators for 1996-2002.' Policy Research Working Paper 3106. World Bank, Washington, D.C. 


\section{CESifo Working Paper Series}

for full list see www.cesifo-group.org/wp

(address: Poschingerstr. 5, 81679 Munich, Germany, office@cesifo.de)

2945 Andrea Bassanini and Giorgio Brunello, Barriers to Entry, Deregulation and Workplace Training: A Theoretical Model with Evidence from Europe, February 2010

2946 Jan-Emmanuel De Neve, James H. Fowler and Bruno S. Frey, Genes, Economics, and Happiness, February 2010

2947 Camille Cornand and Frank Heinemann, Measuring Agents' Reaction to Private and Public Information in Games with Strategic Complementarities, February 2010

2948 Roel Beetsma and Massimo Giuliodori, Discretionary Fiscal Policy: Review and Estimates for the EU, February 2010

2949 Agnieszka Markiewicz, Monetary Policy, Model Uncertainty and Exchange Rate Volatility, February 2010

2950 Hans Dewachter and Leonardo Iania, An Extended Macro-Finance Model with Financial Factors, February 2010

2951 Helmuth Cremer, Philippe De Donder and Pierre Pestieau, Education and Social Mobility, February 2010

2952 Zuzana Brixiová and Balázs Égert, Modeling Institutions, Start-Ups and Productivity during Transition, February 2010

2953 Roland Strausz, The Political Economy of Regulatory Risk, February 2010

2954 Sanjay Jain, Sumon Majumdar and Sharun W. Mukand, Workers without Borders? Culture, Migration and the Political Limits to Globalization, February 2010

2955 Andreas Irmen, Steady-State Growth and the Elasticity of Substitution, February 2010

2956 Bengt-Arne Wickström, The Optimal Babel - An Economic Framework for the Analysis of Dynamic Language Rights, February 2010

2957 Stefan Bauernschuster and Helmut Rainer, From Politics to the Family: How Sex-Role Attitudes Keep on Diverging in Reunified Germany, February 2010

2958 Patricia Funk and Christina Gathmann, How do Electoral Systems Affect Fiscal Policy? Evidence from State and Local Governments, 1890 to 2005, February 2010

2959 Betsey Stevenson, Beyond the Classroom: Using Title IX to Measure the Return to High School Sports, February 2010

2960 R. Quentin Grafton, Tom Kompas and Ngo Van Long, Biofuels Subsidies and the Green Paradox, February 2010 
2961 Oliver Falck, Stephan Heblich, Alfred Lameli and Jens Suedekum, Dialects, Cultural Identity, and Economic Exchange, February 2010

2962 Bård Harstad, The Dynamics of Climate Agreements, February 2010

2963 Frederick van der Ploeg and Cees Withagen, Is There Really a Green Paradox?, February 2010

2964 Ingo Vogelsang, Incentive Regulation, Investments and Technological Change, February 2010

2965 Jan C. van Ours and Lenny Stoeldraijer, Age, Wage and Productivity, February 2010

2966 Michael Hoel, Climate Change and Carbon Tax Expectations, February 2010

2967 Tommaso Nannicini and Roberto Ricciuti, Autocratic Transitions and Growth, February 2010

2968 Sebastian Brauer and Frank Westermann, A Note on the Time Series Measure of Conservatism, February 2010

2969 Wolfram F. Richter, Efficient Education Policy - A Second-Order Elasticity Rule, February 2010

2970 Tomer Blumkin, Yoram Margalioth and Efraim Sadka, Taxing Children: The Redistributive Role of Child Benefits - Revisited, February 2010

2971 Chang Woon Nam and Georg Wamser, Application of Regionally Varying Additionality Degrees in the Practice of EU Cohesion Policy, February 2010

2972 Ali Bayar, Frédéric Dramais, Cristina Mohora, Masudi Opese and Bram Smeets, Modeling Russia for Climate Change Issues, February 2010

2973 Magnus Söderberg, Informal Benchmarks as a Source of Regulatory Threat in Unregulated Utility Sectors, March 2010

2974 Piotr Wdowiński and Marta Malecka, Asymmetry in Volatility: A Comparison of Developed and Transition Stock Markets, March 2010

2975 Frans van Winden, Michal Krawczyk and Astrid Hopfensitz, Investment, Resolution of Risk, and the Role of Affect, March 2010

2976 Hyun-Ju Koh and Nadine Riedel, Do Governments Tax Agglomeration Rents?, March 2010

2977 Johann K. Brunner and Susanne Pech, Optimum Taxation of Bequests in a Model with Initial Wealth, March 2010

2978 Guglielmo Maria Caporale and Nicola Spagnolo, Stock Market Integration between three CEECs, Russia and the UK, March 2010 
2979 Florian Englmaier, Ales Filipi and Ravi Singh, Incentives, Reputation and the Allocation of Authority, March 2010

2980 Konstantinos Angelopoulos, George Economides and Apostolis Philippopoulos, What is the Best Environmental Policy? Taxes, Permits and Rules under Economic and Environmental Uncertainty, March 2010

2981 Frederick van der Ploeg, Rapacious Resource Depletion, Excessive Investment and Insecure Property Rights, March 2010

2982 Wolfram F. Richter and Christoph Braun, Efficient Subsidization of Human Capital Accumulation with Overlapping Generations and Endogenous Growth, March 2010

2983 Francesco Cinnirella, Marc Piopiunik and Joachim Winter, Why Does Height Matter for Educational Attainment? Evidence from German Pre-Teen Children, March 2010

2984 Bernard Van Praag, Well-being Inequality and Reference Groups - An Agenda for New Research, March 2010

2985 Francesca Barion, Raffaele Miniaci, Paolo M. Panteghini and Maria Laura Parisi, Profit Shifting by Debt Financing in Europe, March 2010

2986 Alexander Haupt and Magdalena Stadejek, The Choice of Environmental Policy Instruments: Energy Efficiency and Redistribution, March 2010

2987 John Komlos and Marek Brabec, The Trend of BMI Values among US Adults, March 2010

2988 Emanuele Massetti and Lea Nicita, The Optimal Climate Policy Portfolio when Knowledge Spills across Sectors, March 2010

2989 Helmut Rainer and Thomas Siedler, Family Location and Caregiving Patterns from an International Perspective, March 2010

2990 Toru Kikuchi and Ngo Van Long, A Simple Model of Service Offshoring with Time Zone Differences, March 2010

2991 Assaf Razin, Efraim Sadka and Benjarong Suwankiri, Migration and the Welfare State: Dynamic Political-Economy Theory, March 2010

2992 Bård Harstad, Buy Coal! Deposit Markets Prevent Carbon Leakage, March 2010

2993 Axel Dreher, Stephan Klasen, James Raymond Vreeland and Eric Werker, The Costs of Favoritism: Is Politically-driven Aid less Effective?, March 2010

2994 Sven Neelsen and Thomas Stratmann, Effects of Prenatal and Early Life Malnutrition: Evidence from the Greek Famine, March 2010

2995 Claude Hillinger and Bernd Süssmuth, The Quantity Theory of Money: An Assessment of its Real Linchpin Prediction, March 2010 
2996 Matthew M. Chingos and Martin R. West, Do More Effective Teachers Earn More Outside of the Classroom?, March 2010

2997 Laurence Jacquet and Dirk Van de gaer, A Comparison of Optimal Tax Policies when Compensation or Responsibility Matter, March 2010

2998 Valentina Bosetti, Carlo Carraro, Romain Duval and Massimo Tavoni, What Should we Expect from Innovation? A Model-Based Assessment of the Environmental and Mitigation Cost Implications of Climate-Related R\&D, March 2010

2999 Scott Alan Carson, Nineteenth Century Stature and Family Size: Binding Constraint or Productive Labor Force?, March 2010

3000 Jukka Pirttilä and Ilpo Suoniemi, Public Provision, Commodity Demand and Hours of Work: An Empirical Analysis, March 2010

3001 Bertrand Candelon and Franz C. Palm, Banking and Debt Crises in Europe: The Dangerous Liaisons?, March 2010

3002 Joan Costa-i-Font and Marin Gemmill-Toyama, Does Cost Sharing really Reduce Inappropriate Prescriptions?, March 2010

3003 Scott Barrett, Climate Treaties and Backstop Technologies, March 2010

3004 Hans Jarle Kind, Tore Nilssen and Lars Sørgard, Price Coordination in Two-Sided Markets: Competition in the TV Industry, March 2010

3005 Jay Pil Choi and Heiko Gerlach, Global Cartels, Leniency Programs and International Antitrust Cooperation, March 2010

3006 Aneta Hryckiewicz and Oskar Kowalewski, Why do Foreign Banks Withdraw from other Countries? A Panel Data Analysis, March 2010

3007 Eric A. Hanushek and Ludger Woessmann, Sample Selectivity and the Validity of International Student Achievement Tests in Economic Research, March 2010

3008 Dennis Novy, International Trade and Monopolistic Competition without CES: Estimating Translog Gravity, April 2010

3009 Yin-Wong Cheung, Guonan Ma and Robert N. McCauley, Renminbising China's Foreign Assets, April 2010

3010 Michel Beine and Sara Salomone, Migration and Networks: Does Education Matter more than Gender?, April 2010 